\title{
Strength and Some Durability Properties of Concrete Containing Rice Husk Ash Produced in a Charcoal Incinerator at Low Specific Surface
}

\author{
A. E. Abalaka* \\ (Received March 28, 2013, Accepted October 29, 2013, Published online November 26, 2013)
}

\begin{abstract}
Strength and some durability properties of concrete containing rice husk ash (RHA) predominantly composed of amorphous silica at a specific surface of $235 \mathrm{~m}^{2} / \mathrm{kg}$ produced using a charcoal incinerator were determined. The maximum ordinary Portland cement (OPC) replacement with the RHA increased with increase in water/binder (w/b) ratio of the concrete mixes. The results show that $15 \%$ OPC could be substituted by the RHA without strength loss at w/b ratio of 0.50 . The split tensile strength generally increased with increase in RHA content for the mixes.
\end{abstract}

Keywords: RHA, incinerator, strength, concrete, pozzolanic reactions.

\section{Introduction}

Controlled incineration of rice husks at a temperature below $800{ }^{\circ} \mathrm{C}$ produces RHA that is predominantly composed of amorphous silica (Howlett 2003). Though different incinerators produce different temperature profiles that may affect the amount of amorphous silica in RHA, the change from amorphous to crystalline silica starts at $800{ }^{\circ} \mathrm{C}$ and transition to crystalline silica is complete at $900{ }^{\circ} \mathrm{C}$ (Howlett 2003).

The hydration of cement produces calcium silicate hydrate (CSH) gels known to give strength and cohesion to concrete. Though there are other solid hydration products in cement paste, $\mathrm{CSH}$ constitute $60 \%$ of hydrated cement paste volume (Peled et al. 2013). The amorphous silica in RHA reacts with lime liberated as a result of cement hydration to produce additional CSH gels that improves concrete strength and durability properties (Yu et al. 1999). The reactivity of RHA in concrete is influenced by the ash properties. Previous studies on RHA suggest that incinerating conditions, pre-incinerating treatment of the rice husk, geographical location and specific surface affects the reactivity of RHA in concrete (Salas et al. 2009; Nehdi et al. 2003; Bui et al. 2005; Givi et al. 2010; Paya et al. 1995, 1997; Kraiwood et al. 2001; Ganesan et al. 2008; Ferraro and Nanni 2012). In addition to the pozzolanic reactions of the amorphous silica, the filler effect of the fine RHA particles in the concrete also improves strength at the interfacial transition zone (ITZ) between aggregate and the cement paste (Bui et al. 2005;

\footnotetext{
Department of Building, Federal University of Technology, Minna, Nigeria.

*Corresponding Author; E-mail: aabalaka@gmail.com Copyright ( $\odot$ The Author(s) 2013. This article is published with open access at Springerlink.com
}

Giaccio et al. 2007). In addition to the amorphous silica content, the specific surface is one significant factor that influences the reactivity of RHA. Literature on optimum ordinary Portland cement (OPC) replacement with RHA show that the RHA used in these studies had high specific surface. e.g. (Ferraro and Nanni 2012) achieved $15 \%$ cement replacement with RHA at a specific surface of $430 \mathrm{~m}^{2} / \mathrm{kg}$ and w/c ratio 0.44; (Ganesan et al. 2008) reported $30 \%$ cement replacement with RHA with specific surface of $36.47 \mathrm{~m}^{2} / \mathrm{g}$ in concrete at $\mathrm{w} / \mathrm{b}$ ratio 0.53 . Though RHA containing high loss on ignition (LOI) milled to high specific surface have been reported to be reactive in concrete (Hwang et al. 2011), it is however important that the un-burnt carbon in RHA should be kept low to prevent coloration in concrete and reduce anti surfactant effect of the un-burnt carbon in concrete.

\section{Materials and Methods}

The RHA used for this study was produced from rice husk sourced from a local rice mill in Minna, using a charcoal incinerator. Minna is a small sized state capital and a university town located in Niger state; a major rice producing state in the middle belt region of Nigeria. After production, the RHA was milled using a commercial hammer mill. Though the level of fineness that could be attained by the commercial mill is lower than laboratory mills, it was chosen for its affordability, rapid milling and accessibility and to determine the extent of cement replacement with the low specific surface RHA produced.

The incinerator for producing the RHA used charcoal as solid fuel. The incinerator consists of two concentric fine steel wire baskets of very small apertures; the smaller and shorter steel basket was placed inside the bigger steel basket and the space between the two filled with rice husk. The 


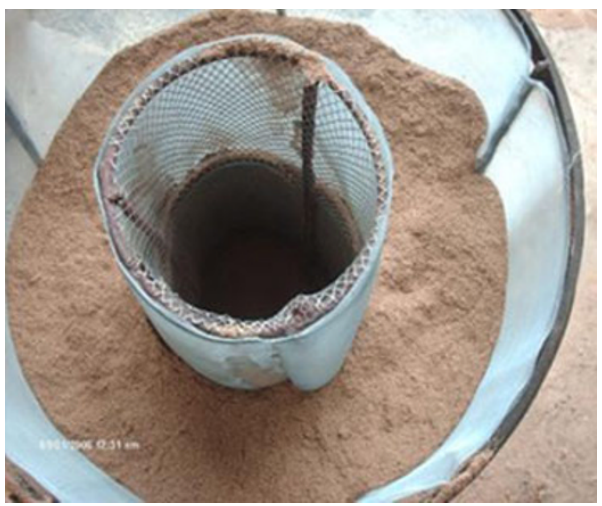

Fig. 1 The incinerator with rice husk.

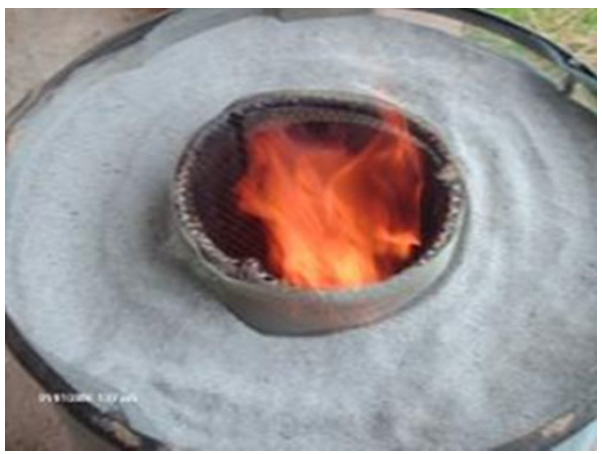

Fig. 2 The incinerator charged with red hot charcoal.

inner steel basket was then charged with red hot charcoal and allowed to burnout. The resulting RHA was allowed to gradually cool to ambient temperature, collected and milled. Using thermocouples, the maximum temperature of the RHA recorded was $758{ }^{\circ} \mathrm{C}$ at less than $4 \mathrm{~h}$ duration and that of the charcoal interior was $838^{\circ} \mathrm{C}$ and less than $4 \mathrm{~h}$ duration. Figures 1 and 2 show the incinerator in use.

River sand [specific gravity $(\mathrm{SG})=2.73, \mathrm{Cc}=1.82$, $\mathrm{Cu}=6]$ was used as fine aggregate; crushed granite of $20 \mathrm{~mm}$ maximum size with specific gravity of 2.63 was used as coarse aggregate. The fine and coarse aggregate particle size distributions are given in Fig. 3. The concrete mix proportions are given in Table 1 . The cement used is a commercial brand of OPC in Nigeria. The composition of the OPC by X-ray florescence (XRF) is shown in Table 2. The compositions of the RHA are given in Table 3.

The concrete was mixed in a drum mixer for $3 \mathrm{~min}$. All samples were demoulded after $24 \mathrm{~h}$ and cured in water at $21{ }^{\circ} \mathrm{C}$ in compliance to BS EN 12390-2 standard (2000). In determining the compressive strength of the concrete, cubes were cast in $100 \mathrm{~mm}$ steel moulds and manually compacted in two layers and tested at determined ages. In determining split tensile strength of the concrete mixes, concrete cylinders were cast in $150 \times 300 \mathrm{~mm}$ steel moulds.

Milled RHA was used dry as percentage cement replacement in the concrete mixes. A laser diffraction particle size analyzer Mastersizer 2000 by Malvern Instruments U.K. was used to determine the specific surface of the RHA.

The compressive strength of the cubes were determined in compliance to BS EN 12390-3 standard (2002) using ELE

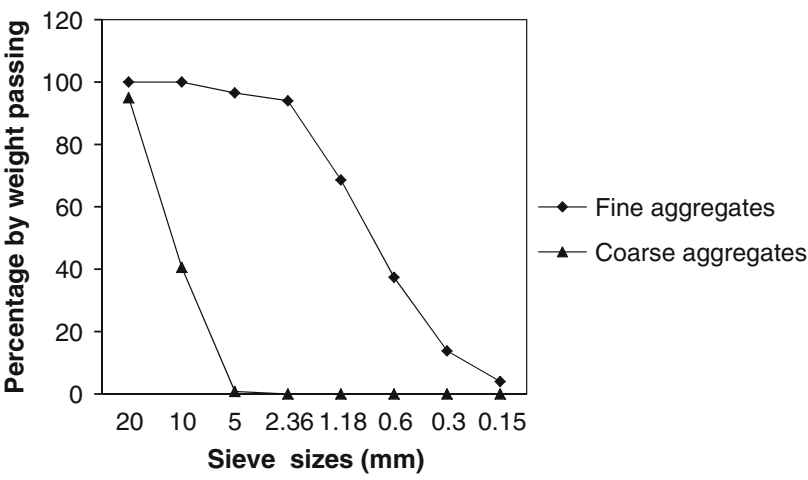

Fig. 3 Particle size distribution of aggregates as percentage by weight passing sieve sizes.

ADR 3000 digital compression machine at a loading rate of $3.00 \mathrm{kN} / \mathrm{s}$; split tensile strength of concrete cylinders were determined in compliance to BS EN 12390-6 standard (2009) using the same machine at a loading rate of $2.10 \mathrm{kN} / \mathrm{s}$. Concrete cubes containing $0 \%$ RHA were used as control.

\subsection{Experimental Methods \\ 2.1.1 Sorptivity}

Sorptivity is a measure of the capillary forces exerted by the pore structure causing fluids to be drawn into the body of the material (Ganesan et al. 2008; Hall 1989). The concrete specimens were heated in an oven at $98{ }^{\circ} \mathrm{C}$ until a constant weight was attained at 10 days and then allowed to cool gradually to room temperature for $24 \mathrm{~h}$. The sides of the cubes were coated with silicone sealant to allow the flow of water on only one surface of the cube specimen. The cube specimens were immersed in water in a shallow pan to a depth of $5 \mathrm{~mm}$ on one surface. The initial mass of the cube was taken; subsequent mass measurement was taken at 4, 8, 10, 20, 30, 60 and $90 \mathrm{~min}$. The sorptivity of the specimens were calculated by using the formula suggested by Stanish et al. (1997).

$$
i=\frac{S}{\sqrt{t}}
$$

$i$ is the cumulative water absorption per unit area of the surface $\left(\mathrm{m}^{3} / \mathrm{m}^{2}\right) ; S$ is the sorptivity $(\mathrm{m} / \sqrt{t})$ and $\mathrm{t}$ is the elapsed time (s). The sorptivity of the specimens were determined after 28 and 90 days of water curing. The setup for the measurement of sorptivity values of the concrete cubes is shown in Fig. 4.

\subsubsection{Saturated Water Absorption}

Percentage water absorption by saturated concrete cubes is a measure of the pore volume or porosity occupied by water. The water absorption values of the concrete cubes were measured as per ASTM C 642 after 28, 90 and 180 days of water curing of the cubes (ASTM 2006).

\section{Results}

Tables 4, 5, 6, 7 and 8 show the effects of OPC replacement with RHA on compressive and split tensile strength of 
Table 1 Concrete mix proportions.

\begin{tabular}{c|c|c|c}
\hline Cement content & Sand & Coarse aggregates & Free w/b ratio \\
\hline \hline $425 \mathrm{~kg} / \mathrm{m}^{3}$ & $446 \mathrm{~kg} / \mathrm{m}^{3}$ & $1,419 \mathrm{~kg} / \mathrm{m}^{3}$ & $0.35,0.40,0.45,0.50,0.55$ \\
\hline
\end{tabular}

Table 2 Composition of OPC by mass using XRF.

\begin{tabular}{c|c|c|c|c|c|c}
\hline $\mathrm{SiO}_{2}$ & $\mathrm{Al}_{2} \mathrm{O}_{3}$ & $\mathrm{Fe}_{2} \mathrm{O}_{3}$ & $\mathrm{CaO}$ & $\mathrm{MgO}$ & $\mathrm{SO}_{3}$ & $\mathrm{~K}_{2} \mathrm{O}$ \\
\hline \hline $24.79 \%$ & $6.35 \%$ & $0.92 \%$ & $58.50 \%$ & $2.87 \%$ & $4.91 \%$ & $0.80 \%$ \\
\hline $\mathrm{Na}_{2} \mathrm{O}$ & $\mathrm{Mn}_{2} \mathrm{O}_{3}$ & $\mathrm{P}_{2} \mathrm{O}_{5}$ & $\mathrm{TiO}_{2}$ & $\mathrm{Cl}$ & $\mathrm{SR}$ & $\mathrm{AR}$ \\
\hline \hline $0.65 \%$ & $0.0 \%$ & $0.15 \%$ & $0.06 \%$ & $0 \%$ & 3.41 & 6.88 \\
\hline
\end{tabular}

$S R$ : silica ratio $=\mathrm{SiO}_{2} /\left(\mathrm{Al}_{2} \mathrm{O}_{3}+\mathrm{Fe}_{2} \mathrm{O}_{3}\right), \mathrm{AR}=$ alumina ratio $=\mathrm{Al}_{2} \mathrm{O}_{3} / \mathrm{Fe}_{2} \mathrm{O}_{3}$.

Table 3 Composition of RHA.

\begin{tabular}{c|c|c|c|c|c|c}
\hline $\mathrm{SiO}_{2}$ & $\mathrm{Al}_{2} \mathrm{O}_{3}$ & $\mathrm{Fe}_{2} \mathrm{O}_{3}$ & $\mathrm{CaO}$ & $\mathrm{MgO}$ & $\mathrm{SO}_{3}$ & $\mathrm{~K}_{2} \mathrm{O}$ \\
\hline \hline $95.41 \%$ & $0.00 \%$ & $0.82 \%$ & $0.00 \%$ & $1.24 \%$ & $0.07 \%$ & $1.65 \%$ \\
\hline $\mathrm{Na}_{2} \mathrm{O}$ & $\mathrm{Mn}_{2} \mathrm{O}_{3}$ & $\mathrm{P}_{2} \mathrm{O}_{5}$ & Specific surface & LOI & Amorphous silica \\
\hline \hline $0.22 \%$ & $0.19 \%$ & $3.97 \%$ & $235 \mathrm{~m}^{2} / \mathrm{kg}$ & $0.77 \%$ & $90 \%$ \\
\hline
\end{tabular}

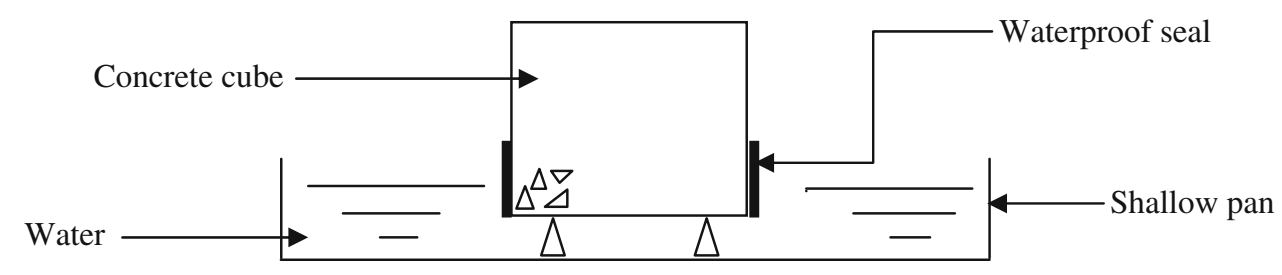

Fig. 4 Sorptivity test.

Table 4 Effects of RHA on strength properties of concrete (free $w / b=0.35$ ).

\begin{tabular}{|c|c|c|c|c|c|c|c|c|}
\hline \multirow{2}{*}{$\begin{array}{c}\text { RHA } \\
\text { replacement } \\
(\%)\end{array}$} & \multicolumn{7}{|c|}{ Average compressive strength $\left(\mathrm{N} / \mathrm{mm}^{2}\right)$} & \multirow{2}{*}{$\begin{array}{r}\text { Tensile } \\
\text { strength } \\
\left(\mathrm{N} / \mathrm{mm}^{2}\right) \\
28 \text { days } \\
\end{array}$} \\
\hline & 3 days & 7 days & 14 days & 21 days & 28 days & 90 days & 180 days & \\
\hline 0 & 44.40 & 45.51 & 52.13 & 54.24 & 55.63 & 65.11 & 66.25 & 3.709 \\
\hline 5 & 27.38 & 37.13 & 39.54 & 40.23 & 46.50 & 49.46 & 54.91 & 3.812 \\
\hline
\end{tabular}

concrete specimens. The effects of RHA on slump, saturated water absorption and sorptivity properties of concrete at different w/b ratio are given in Tables 9, 10, 11, 12 and 13.

\section{Discussions}

The results in Tables 4, 5, 6, 7 and 8 show that as the w/b ratio increased, the amounts of maximum RHA replacements increased, e.g. at a w/b ratio of 0.35 the maximum OPC replacement that could produce a workable concrete was $5 \%$. At a w/b ratio of 0.40 , it increased to $10 \%$ and at $\mathrm{w} / \mathrm{b}$ ratio of 0.45 it increased to $15 \%$. At the w/b ratio of 0.55 , the maximum RHA replacement was $25 \%$. The increase in maximum RHA replacement as the $\mathrm{w} / \mathrm{b}$ ratio increased was as a result of the hygroscopic nature of RHA and its cellular microstructure. Lower $\mathrm{w} / \mathrm{b}$ ratio mixes resulted in lower maximum RHA replacements as less water was available for absorption by the RHA particles. In high w/b ratio mixes more water was available for absorption by the RHA particles resulting in higher replacement levels.

\subsection{Effects of RHA on Strength Properties of Concrete}

The results of compressive strength tests in Tables 4 show that though specimens containing $5 \%$ RHA progressively gained strength with age, specimens containing RHA did not record strength higher than control for all the test ages. The results in Tables 5 and 6 show that compressive strength increases above the control were recorded at $5 \%$ RHA content at $w / b$ ratio of 0.40 and 0.45 at the age of 180 days. At a w/b ratio of 0.40 the strength increase recorded above control was $13.27 \%$ at 180 days and at $w / b$ ratio of 0.45 strength increase recorded above the control was $2.15 \%$ at 180 days. The 
Table 5 Effects of RHA on strength properties of concrete (free $w / b=0.40$ ).

\begin{tabular}{c|c|c|c|c|c|c|c|c}
\hline $\begin{array}{c}\text { RHA } \\
\text { replacement } \\
(\%)\end{array}$ & \multicolumn{9}{|c|}{ Average compressive strength (N/mm ${ }^{2}$} & $\begin{array}{c}\text { Tensile } \\
\text { strength } \\
\left(\mathrm{N} / \mathrm{mm}^{2}\right)\end{array}$ \\
\cline { 2 - 11 } & 3 days & 7 days & 14 days & 21 days & 28 days & 90 days & 180 days & 28 days \\
\hline \hline 0 & 29.28 & 35.35 & 41.71 & 42.78 & 47.93 & 56.14 & 57.79 & 3.553 \\
\hline 5 & 35.78 & 42.85 & 45.29 & 51.21 & 52.81 & 63.19 & 65.46 & 4.097 \\
\hline 10 & 33.71 & 38.20 & 44.28 & 44.24 & 49.87 & 53.44 & 55.02 & 3.669 \\
\hline
\end{tabular}

Table 6 Effects of RHA on strength properties of concrete (free $w / b=0.45$ ).

\begin{tabular}{|c|c|c|c|c|c|c|c|c|}
\hline \multirow{2}{*}{$\begin{array}{c}\text { RHA } \\
\text { replacement } \\
(\%)\end{array}$} & \multicolumn{7}{|c|}{ Average compressive strength $\left(\mathrm{N} / \mathrm{mm}^{2}\right)$} & \multirow{2}{*}{$\begin{array}{c}\begin{array}{c}\text { Tensile } \\
\text { strength } \\
\left(\mathrm{N} / \mathrm{mm}^{2}\right)\end{array} \\
28 \text { days }\end{array}$} \\
\hline & 3 days & 7 days & 14 days & 21 days & 28 days & 90 days & 180 days & \\
\hline 0 & 30.18 & 30.16 & 37.73 & 40.59 & 40.71 & 50.04 & 51.07 & 3.517 \\
\hline 5 & 30.60 & 31.52 & 37.92 & 41.95 & 45.11 & 51.65 & 52.17 & 3.591 \\
\hline 10 & 26.91 & 34.38 & 37.05 & 39.29 & 44.83 & 49.07 & 50.48 & 3.230 \\
\hline 15 & 21.70 & 27.15 & 26.75 & 36.48 & 42.84 & 44.15 & 45.08 & 3.228 \\
\hline
\end{tabular}

Table 7 Effects of RHA on strength properties of concrete (free $w / b=0.50$ ).

\begin{tabular}{|c|c|c|c|c|c|c|c|c|}
\hline \multirow{2}{*}{$\begin{array}{c}\text { RHA } \\
\text { replacement } \\
(\%)\end{array}$} & \multicolumn{7}{|c|}{ Average compressive strength $\left(\mathrm{N} / \mathrm{mm}^{2}\right)$} & \multirow{2}{*}{$\begin{array}{l}\begin{array}{r}\text { Tensile } \\
\text { strength } \\
\left(\mathrm{N} / \mathrm{mm}^{2}\right) \\
28 \text { days }\end{array} \\
\end{array}$} \\
\hline & 3 days & 7 days & 14 days & 21 days & 28 days & 90 days & 180 days & \\
\hline 0 & 23.36 & 26.47 & 34.93 & 33.61 & 37.57 & 39.33 & 45.98 & 2.618 \\
\hline 5 & 24.90 & 27.62 & 33.60 & 34.68 & 38.80 & 45.18 & 46.85 & 3.476 \\
\hline 10 & 25.17 & 30.53 & 30.01 & 35.86 & 44.90 & 44.00 & 49.42 & 3.389 \\
\hline 15 & 25.19 & 31.06 & 37.11 & 36.22 & 41.33 & 39.89 & 46.66 & 3.694 \\
\hline 20 & 19.91 & 26.02 & 29.83 & 37.90 & 32.81 & 36.89 & 39.11 & 3.294 \\
\hline
\end{tabular}

Table 8 Effects of RHA on strength properties of concrete (free w/b $=0.55$ ).

\begin{tabular}{|c|c|c|c|c|c|c|c|c|}
\hline \multirow{2}{*}{$\begin{array}{c}\text { RHA } \\
\text { replacement } \\
(\%)\end{array}$} & \multicolumn{7}{|c|}{ Average compressive strength $\left(\mathrm{N} / \mathrm{mm}^{2}\right)$} & \multirow{2}{*}{$\begin{array}{r}\text { Tensile } \\
\text { strength } \\
\left(\mathrm{N} / \mathrm{mm}^{2}\right) \\
28 \text { days } \\
\end{array}$} \\
\hline & 3 days & 7 days & 14 days & 21 days & 28 days & 90 days & 180 days & \\
\hline 0 & 21.24 & 25.75 & 31.47 & 30.71 & 34.86 & 40.27 & 42.95 & 3.297 \\
\hline 5 & 21.34 & 27.28 & 32.94 & 34.82 & 37.72 & 41.08 & 44.10 & 3.812 \\
\hline 10 & 19.09 & 29.57 & 29.05 & 34.13 & 35.53 & 38.75 & 42.88 & 3.834 \\
\hline 15 & 18.96 & 24.53 & 29.19 & 34.40 & 34.13 & 37.75 & 41.61 & 3.483 \\
\hline 20 & 18.07 & 24.06 & 28.33 & 32.73 & 32.84 & 35.81 & 38.82 & 3.182 \\
\hline 25 & 17.01 & 21.07 & 26.29 & 30.60 & 29.38 & 33.45 & 34.71 & 3.176 \\
\hline
\end{tabular}

Table 9 Effects of RHA on slump, saturated water absorption and sorptivity properties of concrete (free w/b ratio $=0.35$ ).

\begin{tabular}{c|c|c|c|c|c|c}
\hline $\begin{array}{c}\text { RHA replacement } \\
(\%)\end{array}$ & Slump (mm) & \multicolumn{3}{|c|}{ Saturated water absorption (\%) } & \multicolumn{3}{c}{ Sorptivity $i(m / \sqrt{t}) \times 10^{-5}$} \\
\cline { 3 - 7 } & & 28 days & 90 days & 180 days & 28 days & 90 days \\
\hline \hline 0 & 1 & 4.7 & 4.4 & 3.3 & 2.04 & 1.46 \\
\hline 5 & 2 & 5.0 & 5.8 & 5.6 & 2.45 & 2.25 \\
\hline
\end{tabular}


Table 10 Effects of RHA on slump, saturated water absorption and sorptivity properties of concrete (free w/b ratio $=0.40)$.

\begin{tabular}{c|c|c|c|c|c|c}
\hline $\begin{array}{c}\text { RHA replacement } \\
(\%)\end{array}$ & Slump (mm) & \multicolumn{3}{|c|}{ Saturated water absorption (\%) } & \multicolumn{3}{|c}{ Sorptivity $i(m / \sqrt{t}) \times 10^{-5}$} \\
\cline { 3 - 7 } & & 28 days & 90 days & 180 days & 28 days & 90 days \\
\hline \hline 0 & 3 & 5.8 & 5.3 & 5.0 & 2.86 & 2.18 \\
\hline 5 & 5 & 5.9 & 5.6 & 5.5 & 2.59 & 2.11 \\
\hline 10 & 2 & 6.0 & 5.7 & 5.0 & 2.45 & 1.67 \\
\hline
\end{tabular}

Table 11 Effects of RHA on slump, saturated water absorption and sorptivity properties of concrete (free w/b ratio $=0.45$ ).

\begin{tabular}{c|c|c|c|c|c|c}
\hline $\begin{array}{c}\text { RHA replacement } \\
(\%)\end{array}$ & Slump (mm) & \multicolumn{3}{|c|}{ Saturated water absorption (\%) } & \multicolumn{3}{|c}{ Sorptivity $i(m / \sqrt{t}) \times 10^{-5}$} \\
\cline { 3 - 7 } & & 28 days & 90 days & 180 days & 28 days & 90 days \\
\hline \hline 0 & 3 & 5.8 & 5.7 & 5.6 & 2.45 & 2.18 \\
\hline 5 & 30 & 6.0 & 6.4 & 6.4 & 2.10 & 2.05 \\
\hline 10 & 3 & 6.7 & 6.7 & 6.2 & 2.00 & 1.91 \\
\hline 15 & 0 & 7.0 & 6.9 & 6.2 & 1.50 & 0.90 \\
\hline
\end{tabular}

Table 12 Effects of RHA on slump, saturated water absorption and durability properties of concrete (free w/b ratio $=0.50)$.

\begin{tabular}{c|c|c|c|c|c|c}
\hline $\begin{array}{c}\text { RHA replacement } \\
(\%)\end{array}$ & Slump (mm) & \multicolumn{3}{|c|}{ Saturated water absorption (\%) } & \multicolumn{3}{|c}{ Sorptivity $i(m / \sqrt{t}) \times 10^{-5}$} \\
\cline { 3 - 7 } & & 28 days & 90 days & 180 days & 28 days & 90 days \\
\hline \hline 0 & 24 & 6.8 & 6.7 & 6.4 & 1.88 & 1.23 \\
\hline 5 & 90 & 6.6 & 7.0 & 6.9 & 3.74 & 1.19 \\
\hline 10 & 23 & 6.7 & 7.0 & 6.5 & 2.86 & 1.17 \\
\hline 15 & 3 & 7.4 & 7.7 & 6.6 & 3.13 & 3.12 \\
\hline 20 & 1 & 8.0 & 8.8 & 6.7 & & \\
\hline
\end{tabular}

Table 13 Effects of RHA on slump, saturated water absorption and sorptivity properties of concrete (free w/b ratio $=0.55)$.

\begin{tabular}{c|c|c|c|c|c|c}
\hline $\begin{array}{c}\text { RHA replacement } \\
(\%)\end{array}$ & Slump (mm) & \multicolumn{3}{|c|}{ Saturated water absorption (\%) } & \multicolumn{3}{|c}{ Sorptivity $i(m / \sqrt{t}) \times 10^{-5}$} \\
\cline { 3 - 7 } & & 28 days & 90 days & 180 days & 28 days & 90 days \\
\hline \hline 0 & 35 & 6.3 & 6.6 & 6.3 & 2.59 & 1.75 \\
\hline 5 & 100 & 6.5 & 7.4 & 6.8 & 3.49 & 2.31 \\
\hline 10 & 55 & 7.9 & 7.8 & 7.5 & 3.67 & 2.03 \\
\hline 15 & 35 & 8.0 & 8.0 & 6.2 & 3.61 & 3.54 \\
\hline 20 & 27 & 8.1 & 9.7 & 6.8 & 3.54 & 3.00 \\
\hline 25 & 2 & 8.5 & 9.7 & 7.5 & &
\end{tabular}

compressive strength of specimens containing $15 \%$ RHA was recorded to be higher than control at $\mathrm{w} / \mathrm{b}$ ratio of 0.50 at all the test days; at 180 days, the compressive strength increase recorded was $1.48 \%$ higher than control. At a w/b ratio of 0.55 , compressive strength higher than control was recorded for all the test days at $5 \%$ RHA content; at 180 days, the strength increase above control was $2.68 \%$. Water appears to play an important role in RHA reactivity in concrete as strength increase was not recorded at low $\mathrm{w} / \mathrm{b}$ ratio of 0.35 . The results at $\mathrm{a} \mathrm{w} / \mathrm{b}$ ratio of 0.35 and 0.55 suggests that optimum free water is needed for the activation of pozzolanic activity of the RHA particles; where the free water was low, no reactivity was recorded and where it was high no strength gains were recorded.
The results generally indicate that the RHA at a low specific surface was reactive in concrete and $15 \%$ of OPC could be replaced by the RHA without strength loss at a w/b ratio of 0.50 . The optimum replacement level recorded in this study agrees with other studies that used RHA at a higher specific surface. The results also suggest that at the cement content used for this study, there is an optimum w/b ratio that would give maximum reactivity of the RHA in concrete that result in optimum replacement level. The compressive strength gains that were recorded for this study suggests that the reactivity that resulted in compressive strength increases were mainly due to the amorphous silica content of the RHA since the specific surface was low. 
The test results in Tables 4, 5, 6, 7 and 8 show that OPC replacement with RHA that resulted in maximum compressive increase also recorded tensile strength increase above that of the control. Tensile strength increases above the control were relatively marginal compared to compressive strength increases for specimens containing RHA at the different $w / b$ ratio tested. Though the high compressive strength of concrete is known to be due to the strength and cohesion of CSH gels, it is also known to be weak in tension. The work of Murray et al. (Murray et al. 2010) suggests that electrostatic and bond forces at the atomic level of silicate chains as the main reason for the compressive strength of concrete and that its weak tensile strength is due to breaks in silicate chains at the atomic level. The growth of more $\mathrm{CSH}$ gels resulting from the pozzolanic reactions of the RHA would have contributed to the tensile strength increase recorded for cylinders containing RHA.

\subsection{Sorptivity}

The results of sorptivity test in Table 9 show that specimens containing RHA had sorptivity values higher than control. The RHA particles at this $\mathrm{w} / \mathrm{b}$ ratio did not result in pozzolanic reactions that could improve the packing of particles but resulted in increased water absorption. The sorptivity of the specimens reduced at lower w/b ratio mixes and RHA content, but increased as the RHA content increased at higher $\mathrm{w} / \mathrm{b}$ ratio mixes; due to the hygroscopic nature of RHA. The RHA addition would have reduced the capillary of the concrete due to the filler effects and the growth of more $\mathrm{CSH}$ gels from pozzolanic reactions. At 90 days as hydration continued, the permeability further reduced resulting in reductions in sorptivity recorded at 90 days compared to 28 days. Tables 12 and 13 show that at 28 days, as the RHA content increased, the permeability of the concrete increased above the control due to the hygroscopic nature of the RHA.

\subsection{Saturated Water Absorption and Slump}

The saturated water absorption of the specimens containing RHA at w/b ratio of 0.35 was recorded to have increased above the control; the RHA particles that were not used in pozzolanic reactions absorbed water that resulted in increased water intake. Marginal reductions in water absorption of specimens were recorded at 180 days compared to 90 and 28 days.

The slump of the fresh concrete recorded show that higher RHA content resulted in lower slumps for all the mixes except $5 \%$ RHA content. The rapid water absorption of RHA particles due to the cellular microstructure of the particles and the hygroscopic nature resulted in lower slumps recorded. The $5 \%$ RHA content however appeared to have had a different effect on the slump of the fresh concrete as the slumps were higher than that of the control mixes. The $5 \%$ RHA content appeared to have improved the dispersion of the cement particles resulting in higher slumps recorded.

\section{Conclusions}

The results have also shown that the optimum OPC replacement with RHA was dependent on the w/b ratio of the concrete mix. The results show that low $\mathrm{w} / \mathrm{b}$ mixes tended to lower optimum RHA replacement levels. The RHA used has been shown to have improved the tensile strength of the concrete. The results of this study have further shown that, the low specific surface RHA used could replace $15 \%$ of $\mathrm{OPC}$ at $\mathrm{w} / \mathrm{b}$ ratio of 0.50 without reduction in both compressive and tensile strength of concrete.

\section{Open Access}

This article is distributed under the terms of the Creative Commons Attribution License which permits any use, distribution, and reproduction in any medium, provided the original author(s) and the source are credited.

\section{References}

ASTM C642. (2006). Test method for specific gravity, absorption, and voids in hardened concrete. West Conshohocken: ASTM International.

BS EN 12390-2. (2000). Testing hardened concrete. Making and curing specimens for strength tests. London: British Standards Institution.

BS EN 12390-3. (2002). Testing hardened concrete. Compressive strength of test specimens. London: British Standards Institution.

BS EN 12390-6. (2009). Testing hardened concrete. Tensile splitting of test specimens. London: British Standards Institution.

Bui, D. D., Hu, J., \& Stroeven, P. (2005). Particle size effect on the strength of rice husk ash blended gap-graded Portland cement concrete. Cement and Concrete Composites, 27(3), 357-366.

Ferraro, R. M., \& Nanni, A. (2012). Effect of off-white rice husk ash on strength, porosity, conductivity and corrosion resistance of white concrete. Construction and Building Materials, 31, 220-225.

Ganesan, K., Rajagopal, K., \& Thangavel, K. (2008). Rice husk ash blended cement: Assessment of optimal level of replacement for strength and permeability properties of concrete. Construction and Building Materials, 22(8), $1675-1683$.

Giaccio, G., Rodrı'guez de Sensale, G., \& Zerbino, R. (2007). Failure mechanism of normal and high-strength concrete with rice-husk ash. Cement and Concrete Composites, 29(7), 566-574.

Givi, A. N., Rashid, S. A., Aziz, F. N. A., \& Salleh, M. A. M. (2010). Contribution of rice husk ash to the properties of mortar and concrete: A review. Journal of American Science, 6(3), 157-165. 
Hall, C. (1989). Water sorptivity of mortars and concretes: A review. Magazine of Concrete Research, 41(14), 51-61.

Howlett, L. (2003). Rice husk ash market study. Available at http://www.berr.gov.uk/files/file15138.pdf. Accessed 20 Feb 2013.

Hwang, C. L., Bui, L. A., \& Chen, C. C. (2011). Effect of rice husk ash on the strength and durability characteristics of concrete. Construction and Building Materials, 25, 37683772 .

Kraiwood, K., Chai, J., Smith, S., \& Seksun, C. (2001). A study of ground coarse fly ashes with different finenesses from various sources as pozzolanic materials. Cement and Concrete Composite, 23, 335-343.

Murray, J. S., Subramani, V. J., Selvam, R. P., \& Hall, K. D. (2010). Molecular dynamics to understand the mechanical behavior of cement paste. Journal of Transportation Research Board, 21(42), 75-82.

Nehdi, M., Duquette, J., \& El Damatty, A. (2003). Performance of rice husk ash produced using a new technology as a mineral admixture in concrete. Cement and Concrete Research, 33(8), 1203-1210.

Paya, J., Monzo, J., Borrachero, M. V., Peris, E., \& GonzalezLopez, E. (1997). Mechanical treatment of fly ashes. Part III: studies on strength development on ground fly ash cement mortars. Cement and Concrete Research, 27(9), 1365-1377.

Paya, J., Monzo, J., Peris-Mora, E., Borrachero, M. V., Tercero, R., \& Pinillos, C. (1995). Early-strength development of Portland cement mortars containing air classified fly ashes. Cement and Concrete Research, 25(2), 449-456.

Peled, A., Castro, J., \& Weiss, W. J. (2013). Atomic force and lateral force microscopy (AFM and LFM) examinations of cement and cement hydration products. Cement and Concrete Composites, 36, 48-55.

Salas, A., Delvasto, S., Mejía de Gutierrez, R., \& Lange, D. (2009). Comparison of two processes for treating rice husk ash for use in high performance concrete. Cement and Concrete Research, 39(9), 773-778.

Stanish, K. D., Hooton, R. D., \& Thomas, M. D. A. (1997). Testing the chloride penetration resistance of concrete: a literature review, FHWA contract DTFH61 1997. Department of civil engineering (pp. 19-22). Toronto: University of Toronto.

Yu, Q., Sawayama, K., Sugita, S., Shoya, M., \& Isojima, Y. (1999). The reaction between rice husk ash and $\mathrm{Ca}(\mathrm{OH})_{2}$ solution and the nature of its product. Cement and Concrete Research, 29, 37-43. 